\title{
RADON LEVELS IN KARST CAVES IN SLOVENIA
}

\section{RADON V SLOVENSKIH KRAŠKIH JAMAH}

\author{
Janja VAUPOTIČ ${ }^{1}$
}

\begin{abstract}
UDC 911:551.44:539.16(497.4)

Janja Vaupotič: Radon levels in Karst caves in Slovenia

A review is given on the radon survey in the Slovenian karst caves, those open for tourists and those for cavers and speleologists only. Radon concentrations differed markedly from cave to cave, as well as from point to point in the same cave. In addition to radon, in the Postojna Cave also radon decay products (RnDP), equilibrium factor between radon and RnDP, and the unattached fraction of RnDP have been monitored. Based on high radon levels, permanent radon monitoring was introduced in Postojna Cave and time spent by workers in the cave limited in order to keep their exposure to radon acceptably low.

Keywords: karst caves, radon, radon decay products, nano aerosols, diurnal variations of radon, seasonal variations of radon, radon dosimetry, Postojna Cave.
\end{abstract}

Izvleček

UDK 911:551.44:539.16(497.4)

Janja Vaupotič: Radon v Slovenskih kraških jamah

Podajamo pregled raziskav radona v slovenskih turističnih in ne-turističnih kraških jamah. Koncentracije radona se znatno spreminjajo od jame do jame, prav tako pa tudi znotraj posamezne jame. Poleg radona smo v Postojnski jami spremljali tudi radonove kratkožive razpadne produkte (RnDP), faktor ravnotežja med radonom in $\mathrm{RnDP}$ in ne-vezani del RnDP. Zaradi povišane koncentracije radona je bil $\mathrm{v}$ Postojnski jami uveden stalni radiološki nadzor, čas, ki ga delavci smejo preživeti v jami pa omejen, da bi ohranili njihovo izpostavljenost radonu na sprejemljivi ravni.

Ključne besede: kraške jame, radon, radonovi razpadni produkti, nano aerosoli, dnevne spremembe radona, spremembe radona $\mathrm{z}$ letnimi časi, dozimetrija radona, Postojnska jama.

\section{INTRODUCTION}

There are almost ten thousand karst caves in Slovenia, of which about twenty are show caves accessible for tourists, and the remainder only for speleologists and cavers. Our laboratory was one of the first worldwide assuming that radon in cave air might appear at elevated levels, an assumption later confirmed for caves both used for tourist visits (Field 2007) and speleotherapy (Lettner et al. 1996; Kavási et al. 2003; Somlai et al. 2007; Nagy et al. 2009). The first radon measurements in Postojna Cave and the Škocjan Caves were carried out in 1978 (Kobal et al. 1978), only very shortly after the first two reports became available on radon in Bulgarian caves (Vabranov et al. 1975) and in the Carlsbad Caverns (Wilkening \& Watkins 1976). In several consecutive years, radon was surveyed in all the show caves (Kobal et al. 1986a; Kobal et al. 1987) and 26 other caves not open for visits (Kobal et al. 1986b). Later, more attention has been paid to Postojna Cave (Vaupotič et al. 1998) and the Škocjan Caves, aimed at providing reliable information on radon levels as well as on their diurnal and seasonal variations in order to estimate effective doses to the personnel and to keep them below the acceptable levels.

\footnotetext{
${ }^{1}$ Radon Center, Department of Environmental Sciences, Jožef Stefan Institute, Jamova 39, 1000 Ljubljana, Slovenia, e-mail: janja.vaupotic@ijs.si
}

Received/Prejeto: 04.05.2010 
In the last decade, in addition to regular monitoring in Postojna Cave, the unattached fraction of radon decay products $(\mathrm{RnDP})$, the crucial parameter in radon dosimetry, has been measured in order to determine its dependence and, consequently, the dependence of the effective doses, on meteorological conditions and working regimes (Vaupotič 2008).

In this review, radon measurements in the Slovene karst caves are described chronologically and the results commented on.

\section{MATERIALS AND METHODS}

\section{RADON MEASUREMENTS}

Several complementary techniques have been used. Radon scintillation cells (Kristan \& Kobal 1973; Vaupotič et al. 1992) are in use to obtain instantaneous radon concentrations. Average radon concentrations have been measured by exposing solid state nuclear track detectors (ETD) provided from different manufacturers (Planinić \& Faj 1989; Urban \& Schmitz 1993). After exposure, detectors are sent back to the manufacturer for etching and data evaluation. AlphaGuard radon monitors (Genitron) are used to follow diurnal variations of radon concentration only, while various EQF radon devices (Sarad) also measure variations of $\mathrm{RnDP}$ concentration, equilibrium factor $(F)$ between radon and $\mathrm{RnDP}$, and unattached fraction $\left(f_{\text {un }}\right)$ of RnDP. All these devices have been checked at intercomparison experiments organised regularly by the Slovene Nuclear Safety Administration (Križman 2001) and were recently calibrated in the Radon Chamber at the Henryk Niewodniczański Institute of Nuclear Physics, Polish Academy of Sciences, Kraków, Poland (Kozak et al. 2009).

\section{CALCULATION OF EFFECTIVE DOSES}

Effective doses have been calculated using the general formula (Nero, 1988):

$$
E=\frac{C_{\mathrm{Rn}} \times F}{3700} \times \frac{t}{170} \times D C F
$$

in which $E$ stands for the effective dose (mSv), $C_{\mathrm{Rn}}$ for radon concentration $\left(\mathrm{Bq} \mathrm{m}^{-3}\right), F$ for equilibrium fac- tor, $t$ for time (hours) spent at a place with $C_{\mathrm{Rn}}$, and $D C F$ for dose conversion factor $\left(\mathrm{mSv} \mathrm{WLM}^{-1}\right.$, with 1 WLM being 170-hour exposure to $\mathrm{RnDP}$ concentration of $21 \mu \mathrm{J} \mathrm{m}^{-3}$ potential $\alpha$-energy). Several scenarios have been applied using equation 1 :

- depending on the purpose, $C_{\mathrm{Rn}}$ values have been taken either as obtained with scintillation cells, or read from ETDs, or calculated based on the continuous measurements,

- generally $F=0.40$ has been used, as recommended for radon dosimetry by the Publication 65 of the International Commission on Radiological Protection (ICRP 1994), unless $F$ values obtained with EQF devices were taken for some targeted scientific purposes,

- when concentration of $\mathrm{RnDP}\left(C_{\mathrm{RnDP}}\right)$ was known from EQF devices, $C_{\mathrm{Rn}} \times F$ was replaced by $C_{\mathrm{RnDP}}$,

- for $D C F$, the value deduced from epidemiology, $D C F_{\mathrm{E}}=5 \mathrm{mSv} \mathrm{WLM}^{-1}$, has been used generally, as recommended for workplaces by the Publication 65 of the International Commission on Radiological Protection (ICRP 1994), unless for some targeted scientific purposes the dosimetric approach was applied and dosimetric $D C F_{\mathrm{D}}$ was calculated using Porstendörfer's (1996) empirical equation 2, below, for nasal breathing, based on the measured fractions $\left(f_{\text {un }}\right)$ of the unattached $\mathrm{RnDP}$ :

$$
D C F_{\mathrm{D}}=23 \times f_{\text {un }}+6.2 \times\left(1-f_{\text {un }}\right) .
$$

The scenario applied is always referred to when commenting on the effective doses.

\section{RESULTS AND DISCUSSION}

\section{FIRST RADON MEASUREMENTS IN THE SLOVENIAN CAVES}

The first radon measurements were carried out in 1978 in two large and world-known caves, Postojna Cave and Škocjan Caves. In each cave, air was sampled into scin- tillation cells at 17 points along the tourist guided route (Kobal et al. 1978). All samples were collected between 9:50 and 11:20 a.m. Radon concentrations obtained are shown in Tab. 1. Values in Postojna Cave, except at the last four points close to the entrance, exceeded 
$1,000 \mathrm{~Bq} \mathrm{~m}^{-3}$, while, on the other hand, all values in the Škocjan Caves were below $600 \mathrm{~Bq} \mathrm{~m}^{-3}$. At that time, effective doses for neither the visitors nor personnel working in the caves were estimated. Nonetheless, these results were an important basis to initiate discussion on elevated exposure to radon at the cave workplaces, both with the cave management and the governmental bodies responsible for health and radiation protection.

Tab. 1: Radon concentrations in air $\left(C_{R n}\right)$ at 17 measurement points in the Postojna Cave (air samples taken between 9:50 and 10:45 on March 8, 1978) and at 17 points in the Škocjan Caves (air samples taken between 10:20 and 11:20 on March 15, 1978).

\begin{tabular}{|c|c|c|}
\hline $\begin{array}{l}\text { Measurement } \\
\text { point }\end{array}$ & $\begin{array}{c}\text { Postojna Cave } \\
C_{R n} / \mathrm{Bq} \mathrm{m}^{-3}\end{array}$ & $\begin{array}{c}\text { Škocjan Caves } \\
C_{R n} / B q m^{-3}\end{array}$ \\
\hline 1 & $1,700 \pm 40$ & $400 \pm 20$ \\
\hline 2 & $1,900 \pm 50$ & $530 \pm 30$ \\
\hline 3 & $2,000 \pm 50$ & $370 \pm 20$ \\
\hline 4 & $1,800 \pm 40$ & $510 \pm 30$ \\
\hline 5 & $2,200 \pm 60$ & $280 \pm 20$ \\
\hline 6 & $2,400 \pm 60$ & $270 \pm 20$ \\
\hline 7 & $2,200 \pm 60$ & $180 \pm 20$ \\
\hline 8 & $2,200 \pm 60$ & $270 \pm 20$ \\
\hline 9 & $1,300 \pm 40$ & $190 \pm 20$ \\
\hline 10 & $2,000 \pm 50$ & $270 \pm 20$ \\
\hline 11 & $1,400 \pm 40$ & $170 \pm 20$ \\
\hline 12 & $1,100 \pm 40$ & $130 \pm 10$ \\
\hline 13 & $1,000 \pm 30$ & $<75$ \\
\hline 14 & $740 \pm 30$ & $110 \pm 10$ \\
\hline 15 & $780 \pm 30$ & $<75$ \\
\hline 16 & $780 \pm 30$ & $<75$ \\
\hline 17 & $780 \pm 30$ & $<75$ \\
\hline
\end{tabular}

Tab. 2: Ranges of radon concentration $\left(C_{R n}\right)$ in the Slovene show caves obtained with alpha scintillation cells, date of air sampling, length of duration of a tourist visit, number of measurement points, and the effective doses (E) obtained by a person during a tourist visit.

\begin{tabular}{rlccccr}
\hline No. & Cave name & Date & $\begin{array}{c}\text { Duration } \\
\text { min }\end{array}$ & No. of points & $\begin{array}{c}C_{R n} \text { range } \\
\text { Bq } \text { m }^{-3}\end{array}$ & $\begin{array}{c}E \\
n S v\end{array}$ \\
\hline 1 & Postojna & $08-03-78$ & 80 & 17 & $740-2,400$ & 5,190 \\
\hline 2 & Škocjan & $15-03-78$ & 120 & 17 & $75-530$ & 605 \\
\hline 3 & Tabor & $13-10-85$ & 60 & 7 & $650-5,920$ & 7,613 \\
\hline 4 & Frank's & $13-10-85$ & 10 & 2 & $1,140-1,565$ & 716 \\
\hline 5 & Hell (Pekel) & $17-10-85$ & 45 & 7 & $25-115$ & 140 \\
\hline 6 & Iron & $17-10-85$ & 15 & 2 & $480-510$ & 262 \\
\hline 7 & Pivka/Black & $18-10-85$ & 60 & 8 & $30-70$ & 220 \\
\hline 8 & Planina & $18-10-85$ & 60 & 8 & $65-340$ & 421 \\
\hline 9 & Kostanjevica & $24-10-85$ & 30 & 8 & $20-310$ & 275 \\
\hline 10 & Fairy (Vilenica) & $12-11-85$ & 60 & 7 & $35-830$ & 651 \\
\hline 11 & Smoke Chamber & $12-11-85$ & 60 & 8 & $30-515$ & 462 \\
\hline 12 & Cross Mt. (Križna gora) & $13-11-85$ & 60 & 6 & $85-315$ & 1,371 \\
\hline
\end{tabular}

Initially discussions were not successful and only after more than a decade they resulted in permanent radon monitoring and radon dosimetry in Postojna Cave.

\section{RADON LEVELS IN ALL SHOW CAVES}

In 1985, show caves other than Postojna Cave and Škocjan Caves were also surveyed for radon (Kobal et al. 1986a, b). The number of measurement points differed from cave to cave, depending on its size and geometry. Air samples were collected into scintillation cells during regular tourist visits. Results are summarised in Tab. 2. For comparison also data obtained previously in Postojna Cave and Škocjan Caves are included. Values differed substantially from cave to cave and also from place to place in the same cave. The lowest values were found in the Hell and Pivka/Black caves, while the highest was found in the Tabor Cave. Only in Postojna, Tabor and Frank's caves values exceeded $1,000 \mathrm{~Bq} \mathrm{~m}^{-3}$ and were lower than $830 \mathrm{~Bq} \mathrm{~m}^{-3}$ elsewhere. One should take into account that our measurements were carried out in autumn, and therefore radon levels would be higher in summer, as observed in the Postojna Cave (Kobal et al. 1988). Based on radon concentrations, effective doses received by a person during a visit were calculated. For that purpose, the path was divided into steps covered by the measured radon concentration. The value of the radon concentration at a point was taken to apply from halfway to the previous point to halfway to the next point. For each step effective dose was calculated, using equation 1 , and these doses were summed over all such steps in a cave to give the dose for the entire visit. The scenario with $F=0.40$ and $D C F=5 \mathrm{mSv} \mathrm{WLM}^{-1}$ was applied (ICRP 1994). The effective doses exceeded $1 \mu$ Sv in Postojna, Tabor and Cross Mountain caves and were significantly lower in other caves. Although the highest value was found in Tabor Cave we were mostly concerned about Postojna Cave because of its incomparably higher number of personnel spending the majority of working time in the cave. These results contributed to an increase in general awareness of the radon problem in karst caves and eventually led to the introduction of radon dosimetry in Postojna Cave. 


\section{RADON LEVELS IN CAVES NOT OPEN FOR TOURISTS}

In cooperation with a society of amateur cavers we were able to measure radon also in caves and abysses accessible only for speleologists and cavers. They took scintillation cells to their tours and brought air samples back to be counted in our laboratory (Kobal et al. 1986b). In total, 26 places were surveyed. Results are summarised in Tab. 3. As expected, also here radon concentrations differed substantially from cave to cave and from place to place in the same cave. In some caves and abysses all values were either high (e.g. cave numbers $1,4,5,6,15$ ) or low (e.g. cave numbers 11, 13, 23), but also both high and low values were observed in the same cave at different points, often not far away from each other. Effective doses were not calculated because time spent by cavers and speleologists underground is usually short and rather dependent on the task to be done. After the study had been finished, a meeting was organised and results were

Tab. 3: The Slovene caves (other than show caves) and abysses surveyed for radon: cave number, date of air sampling, number of measurement points, and ranges of radon concentration $\left(C_{R n}\right)$ obtained with alpha scintillation cells.

\begin{tabular}{|c|c|c|c|}
\hline Cave no. & Date & No. of points & $\begin{array}{c}C_{R n} \text { range } \\
B q m^{-3}\end{array}$ \\
\hline 1 & 06-05-84 & 6 & $1,500-2,590$ \\
\hline 2 & $12-05-84$ & 2 & $290-890$ \\
\hline 3 & $19-05-84$ & 6 & $120-700$ \\
\hline 4 & 26-05-84 & 3 & $4,980-6,240$ \\
\hline 5 & $26-05-84$ & 1 & 7,220 \\
\hline 6 & $26-05-84$ & 3 & $3,460-4,990$ \\
\hline 7 & 06-06-84 & 5 & $340-2,010$ \\
\hline 8 & 09-06-84 & 3 & $60-1,160$ \\
\hline 9 & $10-06-84$ & 5 & $40-2,540$ \\
\hline 10 & 11-06-84 & 4 & $15-4,460$ \\
\hline 11 & 07-06-84 & 3 & $<100$ \\
\hline 12 & 28-09-84 & 5 & $100-1,140$ \\
\hline 13 & 28-09-84 & 6 & $<120$ \\
\hline 14 & 21-10-84 & 6 & $70-2,340$ \\
\hline 15 & $27-10-84$ & 4 & $4,740-6,480$ \\
\hline 16 & 28-11-84 & 3 & $<200$ \\
\hline 17 & $25-11-84$ & 4 & $245-4,960$ \\
\hline 18 & $08-12-84$ & 3 & $475-770$ \\
\hline 19 & 09-12-84 & 4 & $170-3,760$ \\
\hline 20 & 03-03-85 & 3 & $110-130$ \\
\hline 21 & $10-03-85$ & 4 & $60-590$ \\
\hline 22 & 16-03-85 & 3 & $270-2,930$ \\
\hline 23 & $17-03-85$ & 5 & $25-95$ \\
\hline 24 & $24-04-85$ & 4 & $90-340$ \\
\hline 25 & 24-03-85 & 3 & $415-1,325$ \\
\hline 26 & $19-05-85$ & 3 & $925-1,570$ \\
\hline
\end{tabular}

presented to the members of different caver societies in order to get them acquainted with the radon problem. In addition, they were invited to take our scintillation cells to check the radon in caves where they expect to spend longer times at potentially elevated radon levels.

\section{DIURNAL AND SEASONAL VARIATIONS OF RADON LEVELS IN CAVES}

In order to see seasonal variations of radon concentration, in 1987 radon was measured every month at 20 points (15 along the tourist guided path and 5 off it) in the Postojna Cave (Fig. 1), using alpha scintillation cells (Kobal et al. 1988). All samples were always taken between 10 and 12 a.m. Results for some points are shown in Fig. 2. Fig. 2a shows the situation in a gallery separated from the main gallery by a door. An obvious increase in radon concentration at both points, before and after the door, is seen in summertime. It had been observed (Hakl et al. 1996) that in horizontal caves the driving force for air movement in the cave is the difference in air temperature in the cave and outdoors, while in vertical caves, it is the difference in barometric pressure at the bottom and top of the cave. The Postojna Cave may be approximated by a horizontal cave in which the air temperature is all the year round constant, in the range $9-10^{\circ} \mathrm{C}$. In winter, the temperature in the cave is higher than outdoors and the cave system works as a huge fire-place with many chimneys: the temperature difference forces radon-rich cave air from the cave through vertical shafts and cracks into the outdoor atmosphere. As a consequence of this chimney effect, fresh air of low radon concentration enters the cave, thus reducing the radon concentration in the cave air. It is not clear whether the enhanced radon concentration in February was caused by relatively higher outdoor air temperature at that time (Fig. 2d). Fig. 2b shows a well-pronounced chimney effect at point 3: Skyscraper (a big hall where the tourist path starts), with elevated radon levels in summer and autumn; but no chimney effect at point 4: Magic Garden (a pocket practically closed from the main air stream). An interesting situation is shown in Fig. 2c. At all three points off the guided path, radon levels are highest in spring, then decrease and are low in summer and diverge in autumn: it is higher at one, and lower at the other two points. These differences in seasonal variation are not surprising because karst caves are usually very complex systems for which a univocal explanation of situations at different points is not trivial and needs thorough investigation (Kies \& Massen 1997). Therefore, the situation found in Postojna Cave may not be simply projected to other caves.

The same study also revealed that in summer, radon concentrations in the afternoon were about two times higher than in the morning. In the afternoon, 


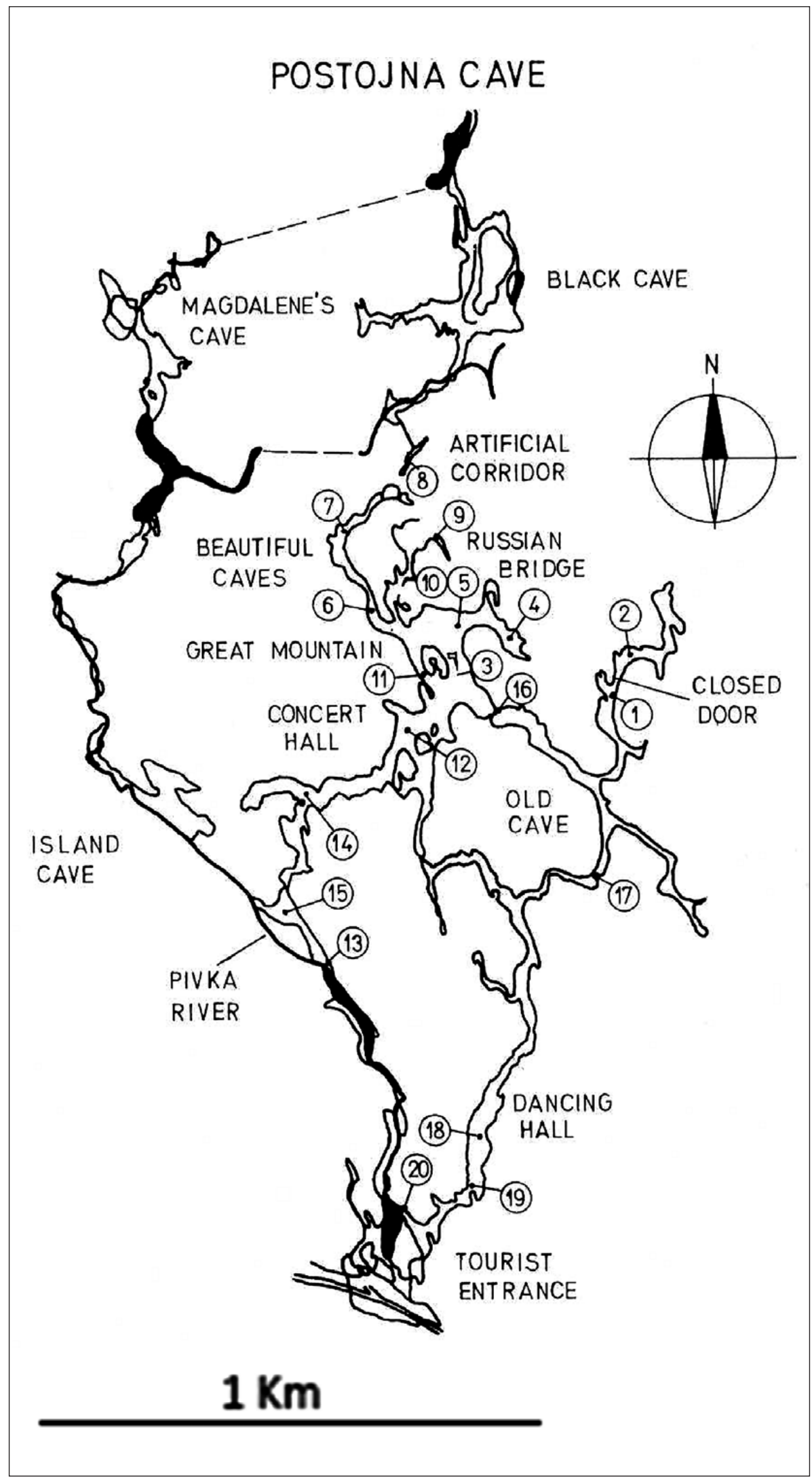

Fig. 1: Ground plan of the Postojna Cave: measuring points are marked with circled numbers. outdoor air temperature is higher than in the morning, thus further reducing the natural air draught from the cave. Detailed information on temporal variation of radon concentration at various points in the cave were obtained later when continuous radon monitoring using active devices became available. Fig. 3 shows diurnal variation of radon concentration as obtained with a weeklong continuous measurement at the Lowest point in Postojna Cave, using a Sarad EQF radon monitor (measurement frequency once per two hours). Minima during nights and maxima during afternoons are well seen.

Knowledge of both seasonal and diurnal variations of radon concentration (as well as other related parameters) is of crucial importance for dose estimates (to be seen later in the text), when we should know the actual radon levels to which persons are exposed, and not only either instantaneous values or monthly or yearly averages.

\section{RADON DOSIMETRY IN THE POSTOJNA} CAVE

Based on the radon levels found and an increased general awareness of radon in caves, the Slovenian Radiation Protection Administration at the Ministry of Health required the management of Postojna Cave to introduce permanent radon monitoring in the cave in 1995. In the first years, the monitoring programme was changed from year to year, based on yearly discussion on the results of the previous year 


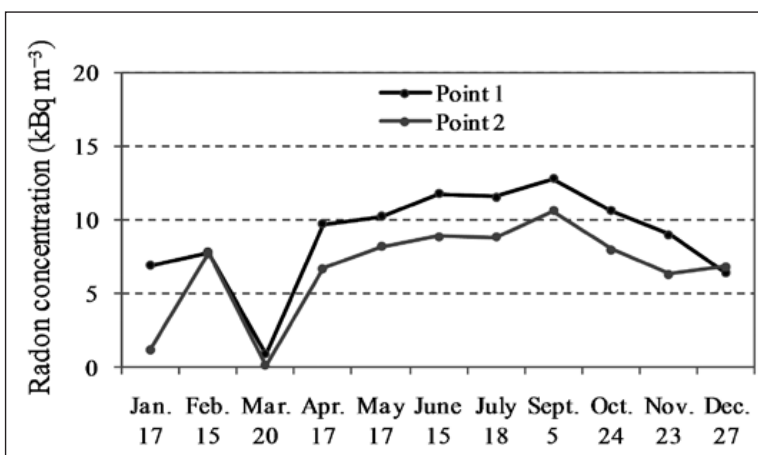

a)

Time (mo) in 1987

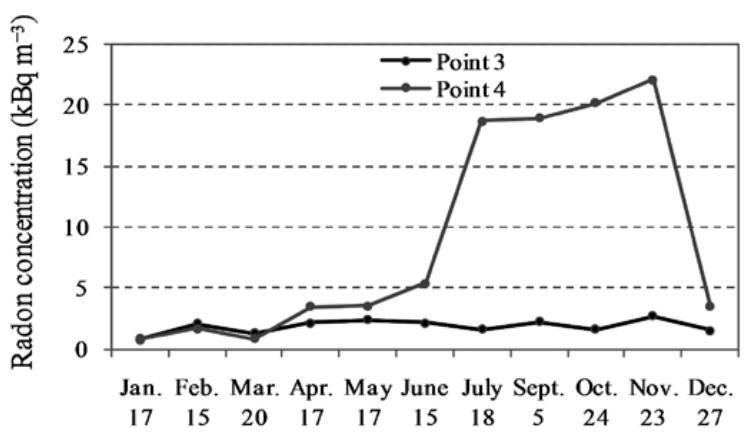

b)

Time (mo) in 1987

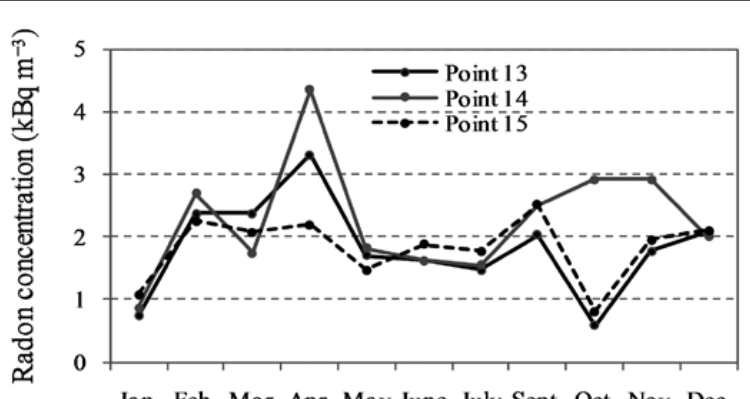

Jan. Feb. Mar. Apr. May June July Sept. Oct. Nov. Dec. $\begin{array}{lllllllllll}17 & 15 & 20 & 17 & 17 & 15 & 18 & 5 & 24 & 23 & 27\end{array}$

c) Time (mo) in 1987

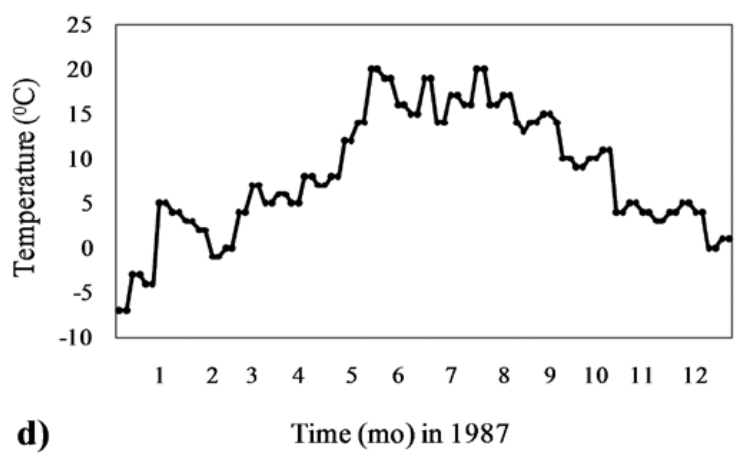

Fig. 2: Seasonal variation of radon concentration in the air of the Postojna Cave at the following measurement points: a) 1: Gay-Coloured Galleries before the door and 2: Gay-Coloured Galleries after the door, b) 3: Skyscraper and 4: Magic Garden, c) 13: Lower Tartar, 14: Upper Tartar and 15: Tartar, and d) outdoor air temperature.

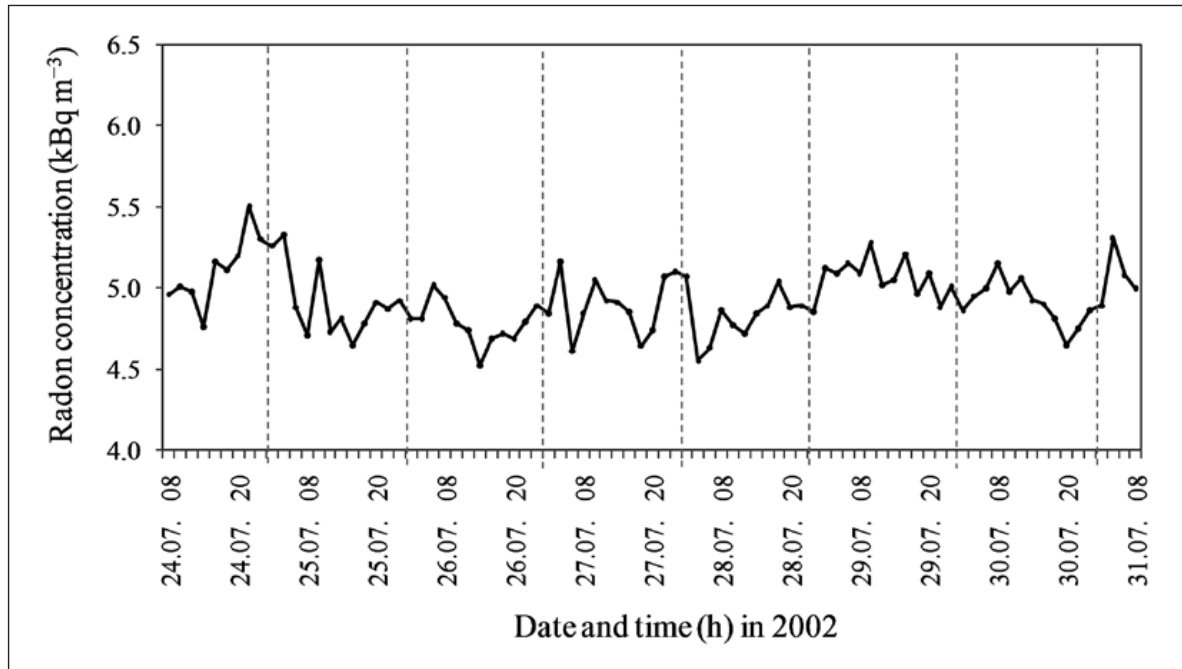

Fig. 3: Diurnal variation of radon concentration in air at the Lowest point in the Postojna Cave on July 24-31, 2002, using a Sarad EQF radon monitor (measurement frequency once per two hours).

(Jovanovič et al. 1992; Vaupotič et al. 1998). The monitoring was eventually optimised in 1999 because of fi- nancial reasons. The number of measurement points was decreased from the original twelve to only two, i.e. the Lowest point and the Train station (starting place of visits), representing reliably enough the situation along the guided path. The following measurements are being carried out yearly: consecutive 3-month exposures of ETDs all the year round and 1-2 week continuous measurements in summer and in winter, using EQF devices, of concentrations of radon and $\mathrm{RnDP}$ and equilibrium factor (Vaupotič et al. 2001). Fig. 4 shows results of such a measurement.

Effective doses for the personnel working in the cave (cave guides, train drivers, electricians, maintenance 


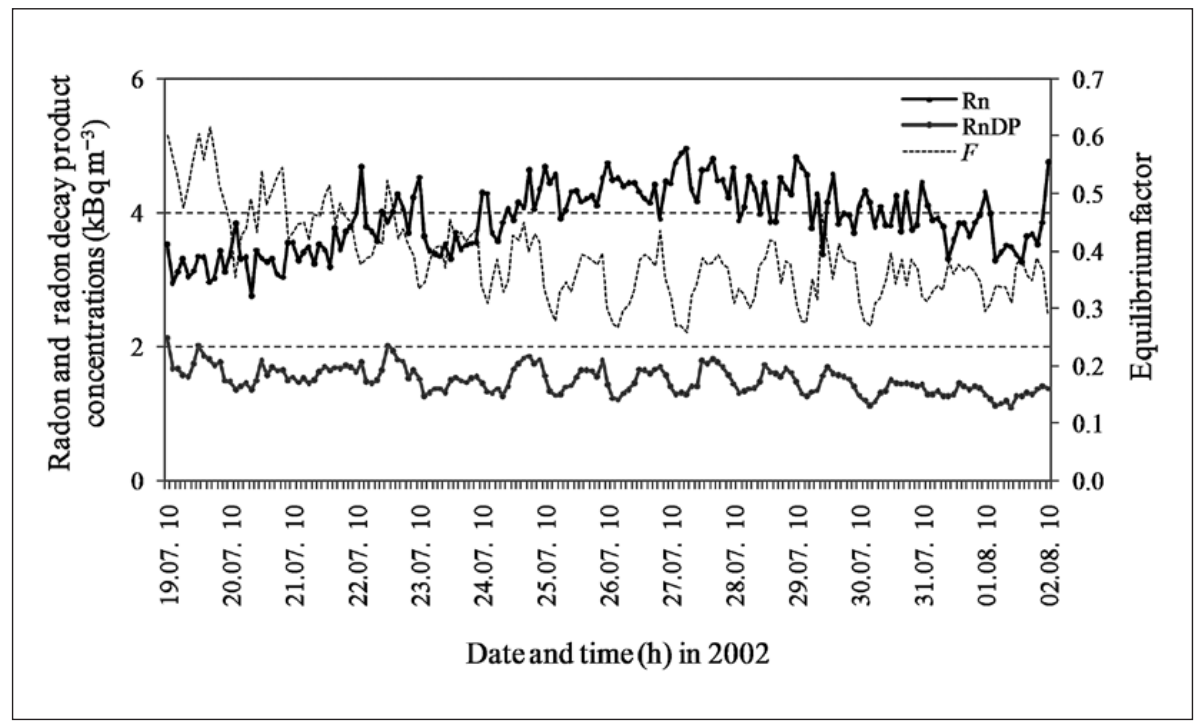

Fig. 4: Results of a continuous measurement of radon and radon decay products concentrations and equilibrium factor in air at the Train station in the Postojna Cave in the period July19-August 2, 2002.

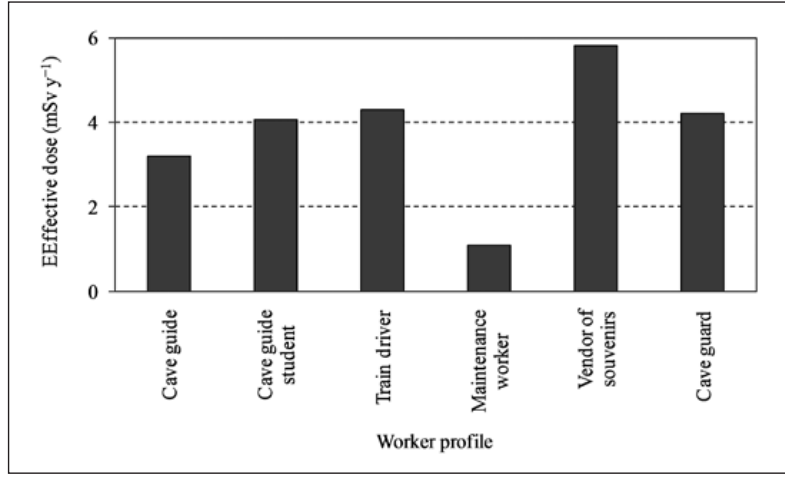

Fig. 5: Average effective doses received in 2004 by workers of different working profiles in the cave.

workers, souvenir vendors, in total about 150 persons) were calculated using equation 1 . In order to fulfil the requirements of the Slovenian Radiation Protection Administration, the values $F=0.55$ and $D C F=5 \mathrm{mSv} \mathrm{WLM}^{-1}$ were used. The management is requested to report doses semi-annually and annually. If the annual effective dose of an employee exceeds $6 \mathrm{mSv}$, the working time of that employee in the cave in the next year is limited. In Fig. 5 average annual effective doses are shown, received in 2004 by workers of different profiles in the cave. As seen, none of working profiles exceed the limit of $6 \mathrm{mSv}$.

\section{RADON DECAY PRODUCTS IN THE POSTOJNA CAVE}

In addition to parameters needed for official radon dosimetry as required by the Slovenian Radiation Protection Administration, also systematic measurements of the unattached fraction $\left(f_{\text {un }}\right)$ of RnDP have been carried out at the Lowest point and the Train station in the Postojna Cave, using the EQF devices. It is well known that

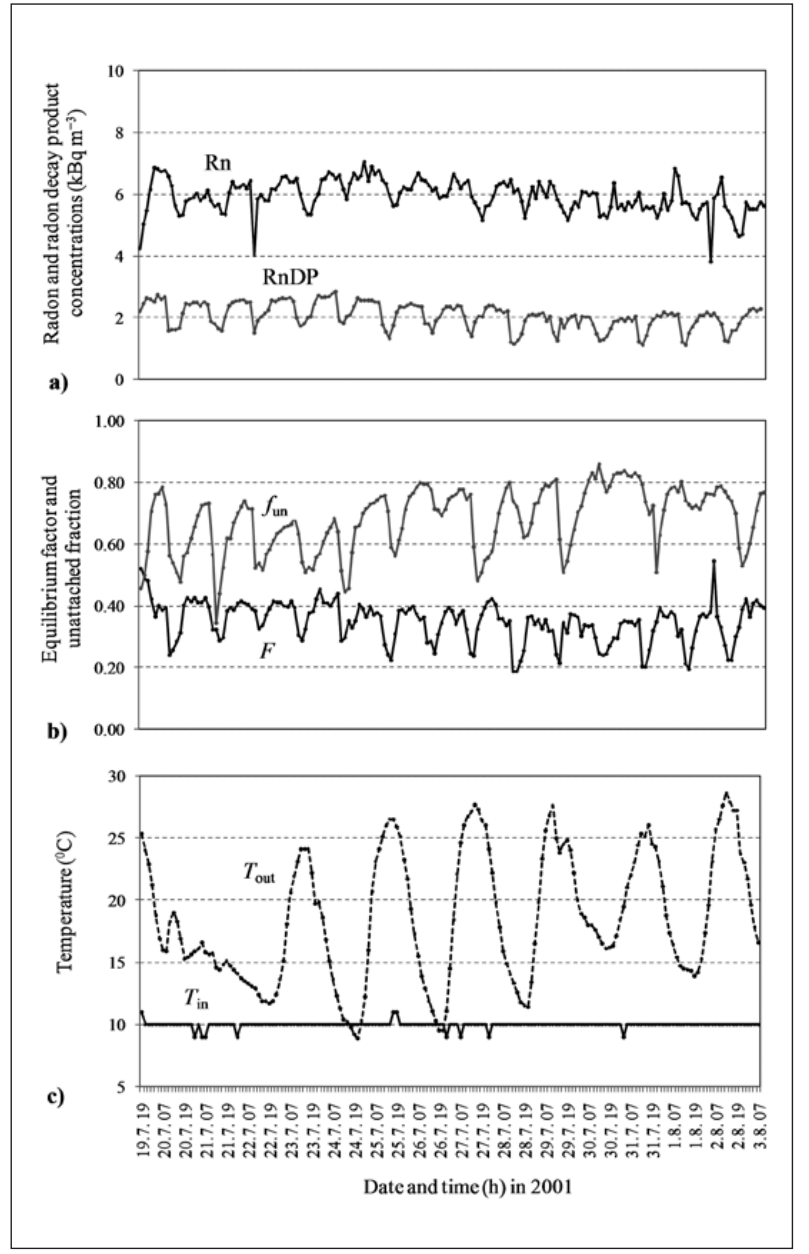

Fig. 6: Results of a continuous measurement of concentrations of a) radon $\left(C_{R n}\right)$ and radon decay products $\left(C_{R n D P}\right)$, b) equilibrium factor $(F)$ and unattached fraction $\left(f_{u n}\right)$ of decay products at the Lowest point in the Postojna Cave and c) temperature in the cave $\left(T_{\text {in }}\right)$ and outdoors $\left(T_{\text {out }}\right)$ in the period July 19 - August 3, 2001. 


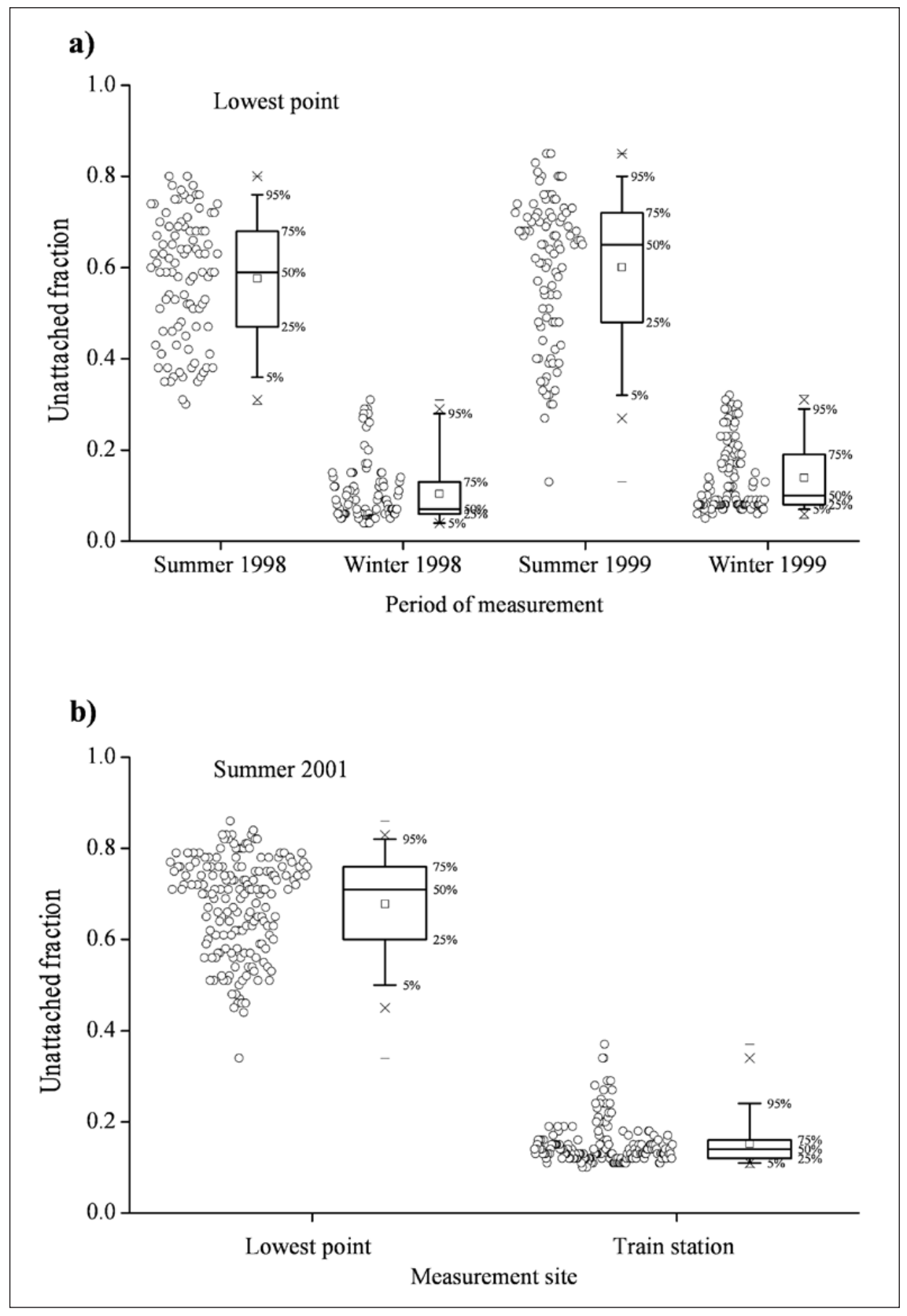

Fig. 7: The box and whisker plot of the unattached fraction $\left(f_{u n}\right)$ of radon decay products in air of the Postojna Cave: a) in different seasons at the Lowest point, and b) at the Lowest point and the Train station in summer 2001

dose conversion factors $\left(D C F_{\mathrm{D}}\right)$ calculated applying dosimetric models are factors higher than those based on the epidemiologic studies (at present: $D C F_{\mathrm{E}}=$ $5 \mathrm{mSv} \mathrm{WLM}^{-1}$ ) (Birchall \& James 1994; Porstendörfer 1996; ICRP 1994). The problem has not been clarified yet (Hofmann et al. 2004; Stather 2004).

For sake of space, only results of one measurement are shown in Fig. 6. It was immediately clear that $f_{\text {un }}$ values are much higher than in indoor air in kindergartens (Vaupotič 2007) and schools (Vaupotič \& Kobal 2006). There are two possible reasons for that: either a low aerosol concentration in air and hence a hindered attachment of decay products to aerosols (Butterweck et al. 1992) or a very high relative air humidity (practically $100 \%$ ) causing washout of aerosols (Paul 1999). In order to prove the first possibility, we recently started measurements of concentration and size distribution of aerosols in the size range $10-1,000 \mathrm{~nm}$ at several

Tab. 4: Dosimetric dose conversion factors $\left(D C F_{\mathrm{D}}\right)$, calculated (using Equation 2) on the basis of unattached fraction ( $f_{\text {un }}$ ) measured in summer and winter at the Lowest point, and their comparison with the epidemiological dose conversion factor $\left(D C F_{E}=5 \mathrm{mSv} W L M^{-1}\right)$.

\begin{tabular}{lccc}
\hline Season & $f_{\text {un }}$ & $D C F_{D}$ & $D C F_{D} / D C F_{E}$ \\
\hline Winter 1998 & 0.09 & 7.7 & 1.5 \\
\hline Summer 1998 & 0.54 & 15.3 & 3.1 \\
\hline Winter 1999 & 0.14 & 8.6 & 1.7 \\
\hline Summer 1999 & 0.61 & 16.5 & 3.3 \\
\hline Summer 2000 & 0.56 & 15.6 & 3.1 \\
\hline Summer 2001 & 0.64 & 17.0 & 3.4
\end{tabular}

points in the cave. As with other measured parameters, diurnal variation is also seen for $f_{\text {un }}$, although not completely understood on the basis of data obtained so far. Seasonal variation of $f_{\text {un }}$ at the Lowest point is shown in Fig. 7a: values in summer are significantly higher than in winter. Fig. $7 \mathrm{~b}$ shows that values are also higher at the Lowest point than at the Train station. Based on the $f_{\text {un }}$ values, $D C F_{\mathrm{D}}$ values were calculated for the Lowest point using equation 2. Results are collected and compared with $D C F_{\mathrm{E}}=5 \mathrm{mSv} \mathrm{WLM}^{-1}$ in Tab. 4 . We see that $D C F_{\mathrm{D}}$ values are always higher, i.e. in winter by a factor $1.5-1.7$ and in summer, 3.1-3.4. 
Although these results are not considered at present routine radon dosimetry, they, together with other data of this kind, form a good database for discussion on the gap between $D C F_{\mathrm{D}}$ and $D C F_{\mathrm{E}}$ values, and may thus contribute to solving this problem.

\section{CONCLUSION}

Radon concentration differed markedly from cave to cave, as well as from point to point in the same cave, ranging from the lower limit of detection of $100 \mathrm{~Bq} \mathrm{~m}^{-3}$ to the highest value of $20 \mathrm{kBq} \mathrm{m}^{-3}$ found in a closed part off the guided route in Postojna Cave in summer. Based on high radon levels found, the cavers and speleologists have been advised to check radon in the caves where they spend longer times, and permanent radon monitoring was introduced in Postojna Cave in order to control the exposure to radon of the personnel working underground, thus keeping their annual effective doses ac- ceptably low. In Postojna Cave, concentration of radon short-lived decay products and their fraction in the unattached form were also monitored. The latter is much higher (0.10-0.68) than in other environments. As a consequence, dose conversion factors obtained by applying the dosimetric models are higher in winter by a factor 1.5-1.7 and in summer, 3.1-3.4 than that derived from epidemiology. This gap between results of the dosimetric and epidemiologic approach remains unexplained and bothers radon dosimetry experts in Slovenia and worldwide.

\section{ACKNOWLEDGEMENTS}

The study was funded by the Government of the Republic of Slovenia, Ministry of High Education, Science and Technology under various contracts. Cooperation of the cave managements and technical assistance of the tourist guides as well as speleologists and amateur cavers in our measurements are appreciated.

\section{REFERENCES}

Birchall, A. \& A.C. James, 1994: Uncertainty analysis of the effective dose per unit exposure from radon progeny and implications for ICRP risk-weighting factors.- Radiation Protection Dosimetry, 53, 133140.

Butterweck, G., Porstendörfer, J., Reineking, A. \& J. Kesten, 1992: Unattached fraction and the aerosol size distribution of the radon progeny in a natural cave and mine atmosphere.- Radiation Protection Dosimetry, 45, 167-170.

Field, S.M., 2007: Risks to cavers and cave workers from exposure to low-level ionizing $\alpha$ radiation from ${ }^{222} \mathrm{Rn}$ decay in caves.- Journal of Cave and Karst Studies, 69, 207-228.

Hakl, J., Csige, I., Hunyadi, I., Varhegyi, A. \& G. Geczy, 1996: Radon transport in fractured porous media - experimental study in caves.- Environment International, 22, 1, 433-437.
Hofmann, W., Fakir, H., Aubieneau-Laniece, I. \& P. Pihet, 2004: Interaction of alpha particles at cellular level - implications for the radiation weighting factor.Radiation Protection Dosimetry, 112, 493-500.

ICRP, 1994: Protection against Radon-222 at Home and at Work.- International Commission on Radiological Protection, ICRP Publication 65.

Jovanovič, P., Kanduč, M. \& B. Kuhar, 1992: Dose estimates due to ${ }^{222} \mathrm{Rn}$ concentrations in Postojna Cave.Radiation Protection Dosimetry, 45, 191-192.

Kavási, N., Somlai, J., Kovács, T., Szabó, T., Várhegyi, A. \& J. Hakl, 2003: Occupational and patient doses in the therapeutic cave, Topolca (Hungary).- Radiation Protection Dosimetry, 106, 263-266. 
Kies, A. \& F. Massen, 1997: Radon generation and transport in rocks and soil.- In: Massen, F. (ed.) The Moestroff Cave - a study on the geology and climate of Luxemburg's largest Maze Cave. Centre de Recherche Public - Centre Universitaire, pp. 159-183, Luxembourg.

Kobal, I., Škofljanec, M. \& D. Zavrtanik, 1978: Radon in karstic caves of Slovenia.- Naše jame, 20, 41-47 (in Slovene with abstract in English).

Kobal, I., Burger, J., Smodiš, B. \& M. Škofljanec, 1986a: Radon air concentrations in Slovene tourist caves.Naše jame, 28, 11-17 (in Slovene with abstract in English).

Kobal, I., Smodiš, B. \& M. Škofljanec, 1986b: Radon-222 air concentrations in the Slovenian karst caves of Yugoslavia.- Health Physics, 50, 830-834.

Kobal, I., Smodiš, B., Burger, J. \& M. Škofljanec, 1987: Atmospheric ${ }^{222} \mathrm{Rn}$ in tourist caves of Slovenia, Yugoslavia.- Health Physics, 52, 473-479.

Kobal, I., Ančik, M. \& M. Škofljanec, 1988: Variation of ${ }^{222} \mathrm{Rn}$ air concentration in Postojna Cave.- Radiation Protection Dosimetry, 25, 207-211.

Kozak, K., Mazur, J., Vaupotič, J., Kobal, I., Janik, M. \& E. Kochowska, 2009: Calibration of the IJS-CRn and IFJ-PAN radon measuring devices in the IFJ-KR-600 radon chamber.- Jožef Stefan Institute, Report number: IJS-DP-10103.

Kristan, J. \& I. Kobal, 1973: A modified scintillation cell for the determination of radon in uranium mine atmosphere.- Health Physics, 24, 103-104.

Križman, M., 2001: Report on the Intercomparison experiment on radon and progeny in air.- Slovene Nuclear Safety Administration, Report number: URSJV RP $47 / 2001$

Lettner, H., Hubmer A. K., Rolle, R. \& F. Steinhäusler, 1996: Occupational exposure to radon in treatment facilities of the radon-spa Badgastein, Austria.- Environment International, 22, 1, S399-S407.

Nagy, K., Berhés, I., Kovács, T., Kávási, N., Somlai, J., Kovács, L., Barna, I. \& T. Bender, 2009: Study on endocronological effects of radon speleotherapy on respiratory diseases.- International Journal of Radiation Biology, 85, 281-290.

Nero, A.V., Jr., 1988: Radon and Its Decay Products in Indoor Air: An Overview.- In: Nazaroff, W.W. \& A.V. Nero, Jr. (eds.) Radon and its Decay Products in Indoor Air. Wiley, pp. 1-53, New York.

Paul, A., Röttger, S., Honig, A., Sulima, T., Buchholz, A. \& U. Keyser, 1999: Measurement of short-lived radon progenies by simultaneous $a \gamma$-spectrometry at the German radon reference chamber.- Nuclear Instruments and Methods in Physics Research A, 434, 303-312.
Planinić, J. \& Z. Faj., 1989: The equilibrium factor F between radon and its daughters.- Nuclear Instruments and Methods in Physics Research A, 278, 550-552.

Porstendörfer, J., 1996: Radon: measurements related to dose.- Environment International, 22, 1, S563S583.

Somlai, J., Kávási, N., Szabó, T., Várhegyi A. \& T. Kovács, 2007: The function of radon in curing respiratory diseases in the therapeutic cave of Tapolca.- Journal of Radioanalytical and Nuclear Chemistry, 273, 363-370.

Stather, J. W., 2004: Dosimetric and epidemiological approaches to assessing radon dose - can the differences be recorded?- Radiation Protection Dosimetry, 112, 487-492.

Urban, M. \& J. Schmitz, 1993: Radon and radon daughters methodology: basic aspects.- In: Fifth International Symposium on the Natural Radiation Environment - tutorial session.- Commision of the European Comunities, Report number: EUR 14411 EN, pp. 151-183.

Vabranov, P., Velikov, V. \& G. Vasilev, 1975: A study of the radioactivity of caves in Bulgaria.- Higiena $i$ Zdraveopazovanie, 18, 491-499 (in Bulgarian with abstract in English).

Vaupotič, J., Ančik, M., Škofljanec, M. \& I. Kobal, 1992: Alpha scintillation cell for direct measurement of indoor radon.- Journal of Environmental Science and Health A, 27, 1535-1540.

Vaupotič, J., Dujmović, P. \& I. Kobal, 1998: Radiation doses due to radon and progeny in Postojna Cave.Acta Carsologica, 27, 395-406.

Vaupotič, J., Csige, I., Radolić, V., Hunyadi, I., Planinić, J. \& I. Kobal, 2001: Methodology of radon monitoring and dose estimates in Postojna Cave, Slovenia.Health Physics, 80, 142-147.

Vaupotič, J. \& I. Kobal, 2006: Radon doses in Slovenian schools based on alpha spectroscopy.- Acta Chimica Slovenica, 53, 8-12.

Vaupotič, J., 2007: Nano-size radon short-lived progeny aerosols in Slovenian kindergartens in wintertime.Chemosphere, 69, 856-863.

Vaupotič, J., 2008: Nanosize radon short-lived decay products in the air of the Postojna Cave.- Science of the Total Environment, 393, 27-38.

Wilkening, M.H. \& D.E. Watkins, 1976: Air exchange and ${ }^{222} \mathrm{Rn}$ concentrations in the Carlsbad Caverns.Health Physics, 31, 139-145. 